\title{
SHIHO MAEDA
}

Shimane University, Japonia

\section{Образ материнской любви в фильме Трясина Григория Чухрая*}

В годы Великой Отечественной войны молодое и старшее поколения поменялись своими ролями. Молодые солдаты погибли в бою, старики их похоронили, женщины оплакивали. Разумеется, в условиях такой масштабной войны, которая развернулась на части территории СССР, люди пожилого возраста, в том числе и женщины, были мобилизованы для работ в тылу, не говоря уже о молодых женщинах ${ }^{1}$. В этом контексте молодое и старое поколения объединяли советский народ в единую семью.

Настоящая статья сосредоточена на проблеме репрезентации образа пожилых женщин, прежде всего матери в советской литературе и кинематографе о Великой Отечественной войне.

Образ матери погибшего солдата играл важную роль в поздней советской символической системе. С одной стороны, в многочисленных памятниках воплощена победа маскулинности, воспеваются солдаты-герои. С другой стороны, фигура оплакивающей матери символизирует скорбь по поводу их гибели. Как мы видим, мемориальное пространство основано на гендерной иерархии ${ }^{2}$.

* Данная работа написана при поддержке JSPS KAKENHI (номера гранта 24720145 и 15KТ0125) и Tohoku University Center for Gender Equality Promotion. Автор статьи благодарит за помощь Эльзу-Баир Гучинову.

${ }^{1}$ См. С. Маэда, Нарратив и репрезентащия женщины на войне: Миф войны и публииистика С. Алексиевич «У войны не женское лицо», [в:] Дальний Восток, близкая Россия: эволючия русской культуры - взгляд из Восточной Азии, ред. В. Гречко, С. Ким, С. Нонака, Белград-Сеул-Саитама 2015, с. 184-198.

2 Подробнее гендерный анализ репрезентации советского памятника павшим на войне показан здесь: S. Maeda, Russia no Senso Kinenhi niokeru Hesi to Hahaoya Image: Kokumin Togo no Gender Balance (Образы солдат и матерей в военных памятниках в России: объединение нации и гендерные роли), „JCAS Review” 2014, № 14-2, с. 17-42 (на японском языке). 
В художественной литературе и в кинокартинах мы встречаем также образ матери, которая отказывается отправлять своего сына на фронт. Это, например, простая крестьянка Матрёна Быстрова, героиня кинофильма Трясина (Мосфильм, 1977) Григория Чухрая (1921-2001) ${ }^{3}$. Ее муж погиб в бою, старший сын Степан пропал без вести на фронте, а потом призвали в армию младшего сына, Митю. Когда Матрена приехала на станцию, где собрались новобранцы, чтобы посмотреть на своего сына, возможно, в последний раз, началась бомбежка. Она привезла потерявшего сознание Митю домой и решила его больше не отпускать на войну. Мать спрятала любимого сына на чердаке.

Если в мемориальной скульптуре образ скорбящей матери считается символом идеального материнства, то указанный в фильме Чухрая образ матери, прятавшей дезертира, воплощает чрезмерную материнскую любовь. Судьба женщины, скрывающей дезертира, описана и сибирским писателем Валентином Распутиным (1937-2015). В повести Живи и помни (1974) жена помогает скрываться в лесу мужу, самовольно покинувшему воинскую часть и вернувшемуся в свое село. В обоих произведениях героини - это простые русские женщины, полные любви, но их судьба трагична, счастье покинуло их. Эти произведения были восприняты и оценены советской властью по-разному. Фильм Чухрая был запрещен к показу на экране, а повесть Распутина была издана тиражом в 1600000 экземпляров, а автор получил за нее государственную награду — Ленинскую премию. Что означает эта разница в оценке произведений, освещавших одну и ту же тему?

\section{Изображение идеальной матери}

Любая пропаганда, относящаяся к теме войны, отражала гендерный порядок своего общества: мужчины защищали Родину, а женщины им помогали в этом. На советских плакатах военного времени часто изображается мать, провожающая сына на фронт ${ }^{4}$, а также Родина-мать ${ }^{5}$. Использование этих образов было направлено на то, чтобы вызвать патриотические чувства у советских людей. Женщина, потерявшая сына, должна поступать как

Методика исследования описана в: N. Tumarkin, The Living and the Dead: the Rise and Fall of the Cult of World War II in Russia, New York 1994.

3 Об истории советского кино о войне подробнее см. D.J. Youngblood, ,, When Will the Real Day Come?" War Films and Soviet Postwar Culture, [в:] «Histories of the Aftermath: The Legacies of the Second World War in Europe», ed. F. Biess, R.G. Moeller, New York 2010, c. 123138. О творчестве Григория Чухрая см. М. Маэда, Grigory Chukhray Kenkyu (Изучение творчества Григория Чухрая), Osaka 2006 (на японском языке).

${ }^{4}$ См. В. Корецкий, Будь героем! 1941, [в:] Шестьсот плакатов, ред. А. Снопков, П. Снопков и А. Шкларук, Москва 2004, с. 89.

5 См. И. Тоидзе, Родина-мать зовет! 1941, [в:] Шестьсот плакатов..., с. 86. 
достойная мать героя, оплакивая и вспоминая погибшего сына до своего последнего дня.

Именно такой образ матери показан в повести Радуга (1942) польской и советской писательницы Ванды Василевской (1905-1964). В произведении рассказывается о жестокости врага на оккупированной советской территории и мужестве советских людей. На основе этого текста Марк Донской поставил в 1944 году одноименный кинофильм. Зрителя впечатляют первые сцены фильма, в которых мать рыдает у мертвого тела своего сына, павшего в бою, не имея права его похоронить.

Современная белорусская писательница Светлана Алексиевич (род. 1948), которая собирала рассказы людей о войне, приводит одну из историй, свидетельствующую о подлинных материнских чувствах:

А тут среди погибших был один местный парень, и на похороны пришла его мать. Стала она оплакивать: «А мой же ты сыночек! А мы ж тебе хаточку будавали! А ты ж обещал, что нам молодую приведешь! А ты же венчаешься с земелькой...». Строй стоит, все молчат, ее не трогают. Потом она подняла голову и увидела, что убит не только ее сын, а много молодых лежит, и она по тем, чужим сыновьям стала плакать: «А мои ж вы сыночки родные! А ваши же мамочки не видят вас, они не знают, что вас в земельку кладут! А земелька такая холодная. А на дворе зима лютая. Так поплачу я вместо них, всех вас пожалею. Мои вы родные... Родненькие...». Она только сказала: «Всех вас пожалею» и «Мои вы родные» - Все мужчины в голос начали плакать ${ }^{6}$.

Образ матери, потерявшей сына, всегда производит сильное впечатление. В католическом искусстве этот универсальный образ называется «Пьета», самым известным воплощением которой является скульптура Микеланджело (1475-1564). Современные художники уже далеки от религиозного благочестия, но тем не менее часто обращаются к этому образу, чтобы выразить скорбь. В 1937 году немецкая скульптор Кэти Кольвиц (Кӓthe Kollwitz, 1867-1945) выразила горе также через образ Пьеты (1937-1938/39)7. В 1993 году копию этой скульптуры поставили в Берлине в мемориальном центре Нойе Baxe (Neue Wache). Надпись у здания гласит: «Жертвам войны и тирании». Скульптура расположена в тихом торжественном пространстве Нойе Вахе, мемориального здания в стиле немецкого классицизма, находящегося в центральной части Берлина (улица Унтер-ден-Линден). До объединения Германии этот мемориальный комплекс находился в восточной части города, поэтому здесь ранее горел вечный огонь и нес службу караул, другими словами, почести павшим на войне отдавали в советском стиле.

В этой связи нельзя оставить без внимания фигуры скорбящей матери (1949), созданной народным художником СССР, скульптором Евгением Вучетичем (1908-1974). Его работа расположена в другом мемориальном комплексе Берлина — Трептов-Парке (Treptower Park).

\footnotetext{
${ }^{6}$ С. Алексиевич, У войны не женское лицо, Москва 2008, с. 364-365.

${ }^{7}$ Ее сын Peter погиб в бою во время Первой мировой войны.
} 
В годы застоя по всему СССР были установлены мемориалы павшим на войне солдатам, и, как правило, представляющие образ скорбящей матери. Мы можем увидеть их на Мамаевом кургане в Волгограде, на Поклонной горе в Москве и в других городах России. Образ матери отождествляется здесь с родиной, которая никогда не забудет подвиги мужчин, поэтому они могут спокойно идти на войну, готовые к смерти.

\section{Трясина}

Кинофильм Трясина не так известен зрителям по сравнению с другими картинами Григория Чухрая о войне, к примеру, Сорок первый (Мосфильм, 1956), Баллада о солдате (Мосфильм, 1959) и Чистое небо (Мосфильм, 1961). Фильм Трясина был снят в 1977 году, и важно, что он был основан на реальных события ${ }^{8}$. Его премьера состоялась в ноябре 1978 года в двух кинотеатрах Москвы. Через четыре месяца эта лента по требованию военного руководства была изъята из общественного доступа, в отличие от других фильмов Чухрая, получивших многочисленные награды и призы на кинофестивалях.

Как говорилось выше, героиня фильма, простая русская женщина по имени Матрена, потеряв мужа и старшего сына, младшего сына «делает» дезертиром. Григорий Чухрай уже обращался к теме материнской любви в фильме Баллада о солдате. Мать героя Алеши продолжает ждать сына даже после его смерти. Ее скорбь и ее любовь разделяет народ. Материнские чувства Матрены имеют такую же силу. Но Матрена умирает. После ее смерти сын Митя перестает прятаться, его дезертирство остается незамеченным. Кстати, режиссер сначала хотел назвать фильм Нетипичная история, но в итоге назвал словом, которое несет в себе осуждающий смысл: Трясина ${ }^{9}$. Несмотря на то, что герои фильма наказаны, военное руководство потребовало прекратить его демонстрацию. Режиссер вспоминал:

Генерал Епишев негодовал, он утверждал, что в армии во время войны не было дезертиров. Он был также обижен «за нашу советскую мать». «Мать, — писал он, — ассоциируется у нас со словом Родина. Показывая мать в отрицательном свете, Чухрай порочит нашу Родину». В «Красной звезде» появилась разгромная статья, были сняты положительные рецензии на фильм, а на студии трудилась комиссия из МК, выяснявшая, куда смотрели партийная организация и директор студии товарищ Сизов, позволившие снять столь вредный фильм. От меня потребовали, чтобы я изменил название картины. По мнению членов комиссии, старое название «Нетипичная история» «бросало вызов основным принципам социалистического реализма». Желая спасти картину, я дал ей название «Трясина». Но это ее не спасло: она была снята с экрана и занесена в список, запрещающий продавать ее за границу ${ }^{10}$.

${ }^{8}$ D.J. Youngblood, ,, When Will the Real Day..., c. 135.

${ }^{9}$ В. Матизен, Загадка Григория Чухрая, http://www.kino-teatr.ru/kino/art/kino/161 (дата обращения: 18.05.2018).

${ }^{10}$ Ibidem. 
В системе официального советского дискурса нельзя было признавать существование дезертирства в рядах Красной армии, хотя широко известный приказ № 227 (в просторечии «Ни шагу назад») очевидно был призван побороть ситуацию с бегством с поля боя. Итоги современных исследований, в которых в настоящее время активно используются методы устной истории (технология опроса, технология расспроса), показывают, что отношение простых людей к государственной политике не сводилось к ее всеобщей поддержке ни перед войной, ни в военное время ${ }^{11}$. Но здесь важно, что военное руководство увидело в образе женщины, укрывающей сына от службы в армии, подлинную угрозу для армии и ее авторитета. Образ Матрены противостоял единству нации ${ }^{12}$. В первых кадрах фильма Матрена появилась в сцене уборки урожая пшеницы, очевидной метафоре плодородного материнства. На фоне лирического русского пейзажа крестьянка Матрена представлена красивой женщиной. Но, потеряв мужа и сына, страдая и нарушая закон, укрывая младшего сыночка, она навсегда теряет мир в своей душе и красоту. В последней сцене, когда она в целях конспирации прогоняет почтальона, принесшего письмо от старшего сына, ее лицо совершенно меняется. Подозрительность и страх делают его напряженным и неприятным. Митя также меняется в худшую сторону. Он не может выходить из дома, поэтому Матрена тоже сидит в четырех стенах, чтобы заботиться о сыне и защищать его.

Особое внимание режиссер уделяет метафорам «движения». Активная жизнь показана в фильме через стремительное движение. Например, беспокойство Матрены о мобилизованном Мите сопровождается движением саней. Люди провожают новобранцев на станцию на санях, Матрена часто останавливается и мешает движению других саней. Эта беспорядочная траектория отражает беспокойное состояние ее души. Обратим внимание на семейную фамилию - Быстровы. Значение фамилии символично.

Когда Степан едет в город, из окна скорого поезда он видит мужчину с факелом на белой лошади и понимает, что произошло что-то важное. Появляются много факелов и транспарант со словом «Победа!» на белой ткани. В следующий миг пассажиры вагона приходят в восторг. Радостная новость пронеслась по всей стране, и ею делились с теми, кто ехал в поезде и еще не знал об этом. Для Степана, оставившего мать и невесту, это не только победа, но и вступление в новую жизнь.

Здесь символически звучит музыка, исполненная в сцене, когда Матрена ищет Митю на станции во время бомбежки. Тогда, воспользовавшись хаотической ситуацией, Матрена вернула Митю с пути на фронт. В обеих сценах иронично переворачивается смерть и возвращение к жизни. В от-

${ }^{11}$ См. C. Merridale, Ivan's War: Life and Death in the Red Army 1939-45, New York 2006.

12 См. B. Anderson, Imagined Communities: Reflections on the Origin and Spread of Nationalism, London-New York 2006. 
личие от Степана, Митя продолжает жить по-старому и остается на чердаке и после победы. Матрена тоже не может далеко отойти от своего дома, так как должна заботиться о сыне и защищать дом от непрошеных гостей.

Когда Матрена спрятала Митю, и они притаились в своем доме, они потеряли что-то важное в жизни. Они не могли радоваться победе, которая взволновала Степана. После окончания войны можно уже не бояться повестки на фронт, но теперь оказалось, что Мите нельзя показаться перед людьми. Он как будто приговорен к вечному заточению на чердаке. Матрена хотела спасти жизнь сына, но получилось, что она отобрала у него жизнь. Режиссер говорит: «Сын остался жив, но мать погубила в нем душу, сделала его несчастным» ${ }^{13}$. Ему пришлось горько раскаяться, когда он увидел из окна чердака свадебное шествие своей любимой девушки. Он мог только сожалеть о потерянной жизни: здоровый, веселый юноша стал «живым трупом». Победа в войне прояснила эту ситуацию.

В конце фильма еще раз показан бегущий пейзаж за окном поезда. Степан едет домой, чтобы познакомить свою мать с женой и показать ребенка. Молодой человек свободен: он может ехать туда, куда хочет. Зрители знают, что его ожидает. Степан еще спокоен и не подозревает, что совершили его мать и брат. Он никогда уже не увидит матери, зато увидит брата. Но эта встреча не будет радостной. Ему придется взять на себя тяжелую ношу, когда он узнает правду. Кадры заканчиваются тяжелым предчувствием.

\section{Чрезмерная материнская любовь}

Теперь остановимся на образе Матрены. Она плохо знает грамоту, что в то время бывало или плохо видит. Соседи и почтальон читают для нее вслух. Ее этика основана на чувствах, а не на разуме. Видимо, ей трудно понимать и принимать логику решений государственной власти. Она без колебаний предпочитает выполнить материнский, а не гражданский долг в трудное для родины время. Надо отметить, что сильные эмоции влияют на состояние ее здоровья. Первый сердечный приступ вызвала новость, что Степан пропал без вести, второй случился, когда Степан покинул дом. Это говорит о том, что героиня любила старшего сына не меньше, чем младшего. Третий приступ произошел от радости, когда Степан сообщил о рождении своего ребенка и своем скором приезде с семьей.

После третьего приступа Митя понимает, что их жизнь — очень тяжелая ноша для пожилой матери, и он решает явиться в органы милиции. Матрена согласна с ним. Ей кажется, что гораздо лучше открыто жить в тюрьме, чем скрываться от людей на чердаке. По ее мнению, даже в тюрьме у сына будет возможность общаться с людьми, вернуться в человеческую жизнь. Митя заявляет, что он готов принять и самую худшую ситуацию, то есть рас-

13 В. Матизен, Загадка Григория Чухрая... 
стрел. Но сердце Матрены больше не выдерживает. Если невесты и жены солдат, потеряв своего жениха или мужа, могут выйти замуж за другого, то для матери замены родному сыну нет. Страх потерять сына разрушает душу Матрены, разбивает ее сердце. После ее смерти оказывается, что ее страдания были напрасными: Митя не был арестован за дезертирство.

Зрители фильма видят, к чему приводит чрезмерная материнская любовь. Здесь трагично звучит простой, казалось бы, вопрос: почему нельзя защищать жизнь своего сына всегда, независимо от ситуации и внешних обстоятельств? Нравственные страдания, вызванные коллизией между долгом перед семьей и долгом перед общиной, воплощены также в истории героини Распутина, молодой сибирской крестьянки Настены. На первый взгляд она похожа на Матрену. Героиня Распутина тоже простая крестьянка, но она - жена солдата, а не мать. Ее муж Андрей скрывается в заброшенной избе в лесу. Настена поставляет ему продукты и предметы первой необходимости. Гибель героини происходит из-за ее беременности, которая в других обстоятельствах могла бы стать радостным событием. Но теперь все село считает ее неверной женой, и свекровь, не знающая о сыне-дезертире, гонит невестку из дома, к тому же, некоторые соседи начинают догадываться, что Андрей находится поблизости. После всего Настена бросается в Ангару, чтобы не выдать дезертировавшего мужа. Это скорее самопожертвование, чем самоубийство. Она не подчиняется своему сообществу и остается верной мужу. В трагедии Настены вступают в неразрешимое противоречие два равных чувства: долг перед мужем и долг перед сельской общиной, то есть народом.

Проанализировав художественные произведения о дезертирах, можно отметить, что власти нуждаются в поддержке женщин на то, чтобы забирать у них мужчин. Для этого они воздают честь женщинам, потерявшим своих сыновей и мужей на фронте, и представляют такой идеальный образ матери, чтобы другие женщины сами стремились к нему. В фильме Чухрая и повести Распутина затрагиваются сложные нравственные проблемы, раскрывается «бессердечность» патриотизма. В обоих произведениях в трудных ситуациях оказались женщины. Настя гибнет, не отвергая сущность гражданского долга, желая одновременно, несмотря ни на что, остаться верной и преданной своему мужу-дезертиру. В фильме Чухрая Матрена сопротивляется идеологии патриотизма, буквально, до смерти. Изображая в фильме материнскую любовь, режиссер показывает ситуацию тех матерей, которые не хотят смириться со смертью своих сыновейсолдат. Обобщая, можно сказать, что Чухрай, рассказывая о материнской любви, ставит вопросы, касающиеся функционирования советской политики памяти о войне. 


\section{Библиография}

Алексиевич С., У войны не женское лицо, Москва 2008.

Корецкий В., Будь героем! 1941, [в:] Шестьсот плакатов, ред. А. Снопков, П. Снопков, А. Шкларук, Москва 2004.

Матизен В., Загадка Григория Чухрая, http://www.kino-teatr.ru/kino/art/kino/161/.

Маэда С., Нарратив и репрезентация женщины на войне: Миф войны и публицистика С. Алексиевич «У войны не женское лицо», [в:] Дальний Восток, близкая Россия: эволюция русской культуры - взгляд из Восточной Азии, ред. В. Гречко, С. Ким, С. Нонака, Белград-Сеул-Саитама 2015.

Тоидзе И., Родина-мать зовет! 1941, [в:] Шестьсот плакатов, ред. А. Снопков, П. Снопков, А. Шкларук, Москва 2004.

Anderson B., Imagined communities: Reflections on the origin and spread of nationalism, London -New York 2006.

Maeda M., Grigory Chukhray Kenkyи (Изучение творчества Григория Чухрая), Osaka 2006 (на японском языке).

Maeda S., Russia no Senso Kinenhi niokeru Hesi to Hahaoya Image: Kokumin Togo no Gender Balance (Образы солдат и матерей в военных памятниках в России: объединение наиии и гендерные роли), „JCAS Review” 2014, № 14-2 (на японском языке).

Merridale C., Ivan's war: Life and Death in the Red Army 1939-45, New York 2006.

Tumarkin N., The Living and the Dead: the Rise and Fall of the Cult of World War II in Russia, New York 1994.

Youngblood D.J., ,, When Will the Real Day Come?” War Films and Soviet Postwar Culture, [B:] «Histories of the Aftermath: The Legacies of the Second World War in Europe», ed. F. Biess, R.G. Moeller, New York 2010.

\section{Image of maternal love in Grigory Chukhray's The Quagmire}

\section{Summary}

Memories of the Great Patriotic War contributed to the making of a national identity in Soviet Russia, and clear gender roles are evident in Soviet propaganda war art. The image of male soldiers demonstrates the obligation to defend the fatherland against the outside enemy. On the other hand, there are images of a mother cheering for her son or a mother lamenting over a fallen soldier. It is clear that the female image belongs to the reproductive function of motherhood. The establishment presents an ideal and urges the public to internalize it by themselves. Grigory Chukhray's film The Quagmire's (1977) mother, however, hides her young son, who was conscripted to the front. The film casts doubt on the Soviet war myth and asks "Why do mothers have to be reconciled to lose their sons in order to defend the fatherland?" That's why the military purged the film from the screen.

Keywords: Soviet, gender, memory, war, motherhood. 


\section{Obraz miłości macierzyńskiej w filmie Grigorija Czuchraja Trzęsawisko}

\section{Streszczenie}

Wspomnienia i obrazy Wielkiej Wojny Ojczyźnianej odegrały ważną rolę w kształtowaniu tożsamości obywateli Rosji Radzieckiej. W sowieckiej propagandzie wojennej wyraźnie widać hierarchię genderową. Wizerunek żołnierza mężczyzny odnosi się do obowiązku obrony ojczyzny przed zewnętrznym wrogiem. Natomiast wizerunek matki wiwatującej na cześć zwycięstwa syna lub rodzicielki lamentującej nad poległym żołnierzem kojarzony jest z macierzyństwem.

Film Grigorija Czuchraja Trzęsawisko (Трясина) opowiada historię matki ukrywającej powołanego do wojska i wezwanego na front syna. Film, który wkrótce po premierze wycofano $\mathrm{z}$ dystrybucji, stawia pytania dotyczące funkcjonowania radzieckich mitów wojennych oraz sytuacji kobiet, które nie chcą się pogodzić ze śmiercią swych synów broniących ojczyzny.

Stowa kluczowe: Rosja Radziecka, gender, pamięć, wojna, macierzyństwo. 